\title{
Work Culture, Digital Governance and Employees Happiness in Pariaman City
}

\author{
Aldri Frinaldi \\ \{ aldri@fis.unp.ac.id, alfrinaldi@gmail.com \} \\ Public Administration Department, Social Science Faculty, Padang State University
}

\begin{abstract}
This study aims to measure employee happiness at work. For this reason, using work culture and e-governance were variable to measure employee happiness. This research used a quantitative method with a survey approach. A sample of 66 respondents was from the various organization of regional devices in Pariaman city. The data processing system was analyzed using a multi-regression and t-test. The study results were based on the value of Adjusted $\mathrm{R}^{2}$, which is the happiness index variable was influenced by the work culture variable, and e-governance was $47.8 \%$. Then, from the probability value, the results of both work culture and e-governance affected the happiness index. Partially, there was an influence of work culture on the happiness index with a significance of 0.03 . Then, $\mathrm{X} 2$ partially had the effect of e-governance on the happiness index with a significant of 0.000 .
\end{abstract}

Keywords: Happiness, Work Culture, Digital Governance, Employees.

\section{Introduction}

In general, Indonesia people prefer to carry out their daily activities, including public service affairs with the government and local governments, which are carried out physically. This is due to cultural factors. Although in various regions there have been many advances in the use of information technology. However, efforts to change physical service habits to digitalbased services are continuously being developed by local governments for cost efficiency, competitiveness, and future survival, and increasing happiness. Because the existence of digital governance has been felt to have advantages in terms of useable in this digital-based information technology advancement. Especially, today various circles of society have started accustomed to becoming users of media-based. It is in line with bureaucracy and its employees must also adjust to the existence of these advances in digital technology.

It is increasingly necessary during the extraordinary circumstances during the Covid-19 outbreak. At this time various countries including Indonesia carried out various efforts to overcome the spread of the outbreak, including in Indonesia the term Large-Scale Social Restrictions (PSBB) which has been known by many people. At this time, the term work from home is widely known, so that the majority of predominantly social life is carried out using digital-based media. Including various state and government affairs in running the wheels of government both at the national level and in various regions. So that the various dynamics of life that take place with various changes today, then the work culture of employees in the public 
sector is mainly driven by the circumstances during the eradication of the epidemic need to change its work culture into a digital-based work culture. Moreover, a circular letter issued by the Minister of Administrative and Bureaucratic Reform (PANRB) No. 19 of 2020 concerning Adjustment of the Work System of State Civil Apparatuses in Preventing the Spread of COVID19 in government agencies. This circular letter applies to work from home in turn for employees in government agencies.

To meet the needs of public accessibility in government administration and public services, there is a change from the conventional form, namely face-to-face changing to a limited conventional, namely direct services that are limited in number and/or carried out using an online system. The use of the online system is a form of further implementation of digital governance development in the context of using online information technology to increase access and delivery of government services to make it easier for the public and stakeholders. This is intended so that the administration of government administration including in the regions is carried out in the form of modern and integrated to reduce various distance and boundary barriers for the community in gaining the accessibility they need. To be able to build a smoother, easier, and more efficient interaction between the government and the public to increase public trust in the government and/or local governments.

In connection with this, the research conducted in writing this article has a theoretical purpose to build a work culture happiness design among employees with the development of local government based on digital governance, the case study in Pariaman city west Sumatra. The novelty of this article lies in the formulation of the values of happiness resulting from digital government policies. Previous researchers stated that the main proposition in expanding the penetration of information and communication technology has an impact on increasing public happiness, so that community interaction with local governments becomes closer.

By digital governance by Mclver Elmagarmid's [1] the government will look more interactively more broadly with the community, in its orientation to disseminate information about governance. [1] states that the use of digital governance also has a big role in designing strategic work in carrying out more democratic government functions.

During this time, it seems as if the public service performed by bureaucratic institutions, especially in local government, is notoriously difficult, complicated, and long standing. However, developments in overcoming this are continuing, one of which is by utilizing digital advances. The existence of digital governance provides broader information openness and transparency by the government to the community, the government to the private sector, and by the government to the government. Also, the implementation of digital governance makes it easy for employees to work [2]. Along with that, the development of digital-based work culture among employees is something that should be done to build a better future.

The existence of a work culture based on digital governance is a form of innovation in organizations. The use of digital makes it easy to carry out work so that a proper, fast, and effective work culture is created. The idea of work culture as a person's environment in doing their job must be able to improve organizational performance [2]. Work culture is also interpreted as a system of shared values that are also used to be able to obtain high performance in an organization [2].

With this work culture, activities carried out to meet community needs can be measured through community satisfaction as recipients and employee satisfaction with the work culture that exists in the organization and can also be measured through satisfaction. However, satisfaction does not necessarily describe employee happiness as well as public happiness, and happiness certainly indicates that they are satisfied. Therefore, for accuracy 
in measurement that will later lead to organizational improvement that is more effective and efficient, a design that can measure happiness from both the community and employee perspectives as objects of an organization's work culture is needed. Existing measurements are not complex yet to measure tangible and intangible a product (goods or services) obtained by the customer. With the formation of this happiness design, it is intended that there will be appropriate improvements by the organization in providing goods and services.

For this design development stage, work culture becomes a predictor variable of people's happiness, and to measure employee happiness, work culture will be an effect variable. Work culture becomes a variable juxtaposed in the development of this variable because the work culture of an organization is a basis on which to hold in the organization. With a good handle on this basis, all actions taken will be following organizational goals.

\subsection{Review of Related Literature Happiness}

The happier someone is the more productive they are at work and able to complete tasks more accurately and have a positive impact on performance. Of course, this is beneficial for government organizations, as well as local government organizations or companies. On the other hand, unhappy employees tend to have lower attendance rates, also experience more fatigue and stress. Employees, who feel happy while working tends to exceed expectations, can achieve goals and perform higher than unhappy employees.

Besides, happy employees are also considered to be more creative. Meanwhile, employees who are not happy with the work environment tend to do less effort at work. Even working together, happy employees are more collaborative. The reason is, happy employees, feel comfortable with each other, and this has an impact on the willingness to share ideas and opinions. Having employees who are open to providing ideas and opinions is certainly beneficial for the institution where he works. Happy employees also have the potential to become better, more efficient, and more motivating leaders. Happy employees make better decisions, are good at time management, work better with others, and have several other important leadership skills.

When employees are happy, they tend to dare to take the bigger risks and take chances. Conversely, unhappy employees choose to play it safe. Happy employees also help create a supportive environment at work. They will encourage everyone to learn from mistakes rather than fear of making mistakes. Things that can encourage happiness at work between the existence of work culture in the form of rewards such as; praise, congratulations, or small parties, all forms of appreciation to employees are effective ways to increase happiness and work motivation. The appreciation from the leadership and colleagues, they can feel the results of the hard work he has put in. Other employees also feel motivated to achieve the same success. Then, work culture in communicating with employees to listen to all the complaints, both with colleagues and with their leaders. This is a valuable factor and can affect employee retention and productivity. Because with this condition, a work environment is built that is considered to care for them.

Happiness can be defined as an assessment based on two sources of information, namely the comparison between the standards that should provide pleasure and information related to the time spent for pleasure [3]. But in general, people often measure happiness from an economic point of view, namely in the aspect of income, but on the other hand, happiness is not always seen from the success aspect of economic income progress, but it can also be how someone or a group of people views their life as having reached a level of prosperity with a measure of satisfaction of life, even though the economic income is not high. Sometimes this happiness can be viewed from a subjective welfare point of view, which according to Diener et 
al [3] calls subjective well-being as a person's cognitive and emotional evaluation of his life. The evaluation includes an emotional reaction to an event as well as a cognitive assessment of the individual's life satisfaction

In concept, happiness is different from satisfaction. Satisfaction refers to awareness in the form of understanding the theory, while happiness refers to things that are affected or things that are felt, and satisfaction can be part of the theoretical aspects of happiness [4]. According to Clark (2008), happiness is not only limited to what is desired but can be seen from life expectancy, morbidity, productivity, absenteeism. For happiness at work, four indicators can be used as a measurement, namely the nature of work, relationships with superiors and colleagues, internal work environment, and external conditions (balance of family life and work-life) [4].

Also, Shimazu et al [5] also measured happiness from three dimensions, namely dedication, enthusiasm, and absorption. Dedicated people are inspired by their work, and they consider their work to be important and a source of pride. The spirit referred to in this dimension is people who have high spirits, have mental endurance and are willing to survive, and invest effort in their work. People who have high absorption are people who enjoy their work, able to let go of the difficulties that occur at work. Also, El-Sholkamy and Fischbach [6] also suggest dimensions of measuring happiness, namely friendliness, activeness, attention, willingness to learn, and giving. Semedo, et al [7] also state that happiness is a multidimensional construction based on affective well-being, competence, aspirations, autonomy, function, and integrative satisfaction.

The factors that determine happiness according to [8] are demography, economy, and political environment. Demographic factors that influence include individual characteristics such as age, gender and family conditions, education, and health. In economic factors, conditions of unemployment, income, and inflation are considered to affect individual happiness. Meanwhile the quality of democracy such as the extent to which the possibility of citizens participating in politics and the degree of decentralization of government is a major component of the condition of the political environment that affects happiness.

According to Aldri and Afriva of happiness [9] suggest that people who visit a tourist location are their efforts to create happiness. Aldri and Afriva [9] express that happiness can be measured using three (3) dimensions, namely; (1) Comfortable, is a person's way/point of view to enjoy the beauty. The indicators are: interesting, fresh, and expressive; (2) Peaceful, is an environmental condition that can produce a relaxed and relaxed atmosphere. The indicators are relaxed and feeling carefree; (3) Positive action is a reflection of positive thinking. The indicators are joy, big heart, and spirit.

Furthermore, according to Diener \& Diener [3] that happiness at work can be interpreted as feeling enthusiastic about work, eager to come to work, having good relationships with colleagues, showing interdependence with other people, or other fields in the workplace, having a good performance. good work, able to get along with other employees, willing to change his friend's work schedule when needed, working on several additional activities aimed at improving the workplace, products, and services to work.

From the view above, it can be seen that happiness is a feeling of enthusiasm that employees feel about their work so that it allows employees to maximize their performance at work. According to [10] happiness at work is influenced by factors that come from within and from outside the employee which can make employees feel happy while working, including factors from within the employee to the organization; a. Can achieve the goals that the employee has. b. Have objectivity to work. c. Raise issues that are considered important to employees. d. Feel safe when working. Factors of organizational conditions on employees; a. Feeling that their opinions are heard by colleagues and leaders. b. Receive positive feedback that can help clarify 
roles, make employees feel better, validate employee work results, increase the sense of being able to control work in the sense of being able to be professional, reduce negative feelings about organizational politics, increase work motivation, and strengthen working relationships between coworkers and leaders. c. Feeling that he is valued at work, which means that he feels valued and valued for who he is. d. Appreciated and treated well by the leaders. and strengthen working relationships between colleagues and leaders.

Based on the description of the experts above, it can be seen that several other factors can cause low happiness in a government or company organization, namely; lack of career development and job promotion opportunities, lack of opportunities for career development. Also, workers felt that the absence of benefits or other benefits could affect their happiness and work culture at work.

In connection with the explanation above, in this study happiness is meant that happiness is a feeling or state of mind of someone who is characterized by a sense of comfort, peace, and encouragement to be more positive. Formulated in 6 components for measuring happiness, namely: (1) the availability of free time that can be obtained at work; (2) interpersonal relationships that take place in the workplace; (3) environment and safety at work; (4) facilities in the workplace; (5) life autonomy which gives freedom in making personal choices in work; (6) integrative function and satisfaction obtained at work.

\section{Digital Governance}

According to Irawan [11], e-Government is the use of the internet to carry out government affairs and provide better public services and service-oriented ways to the community. In summary, the goal to be achieved with e-Government is to create customers online and not in line. Also, e-Government aims to provide services without the intervention of public institution employees and a long queue system just to get a service that is simple, cheap, and effective. Besides, e-Government is also a way for governments to use new technology to provide citizens with convenient access to information and government services, to improve service quality, and to provide greater opportunities for participation in democratic processes and institutions.

Another view, namely according to [12] The function of e-governance includes the functions of e-government and e-democracy, where actors in e-governance are public sector administrators of government consisting of the executive (finance, education, health, etc. ), judiciary, and legislature at the national, regional and local levels. The next actor is called the end-user who according to the concept of governance consists of the non-government sector and the private sector that interacts at five levels of governance.

Meanwhile, according to Zhiyuan Fang [13], E-Government is defined as a way for governments to use innovative information and communication technology, especially webbased internet applications, to provide access to government information and services easier for citizens. This is done to improve the quality of services and provide greater opportunities for the community to participate in the development of government institutions and the democratic process.

According to [11] the important factors of the e-Government development area. External Pressure; The strong demand from stakeholders for the government to improve its services is an important factor because basically, the government is responsive and not yet proactive so that if there are no demands from outside, the government will feel that there is nothing that needs to be improved in its service system; b. Internal Political Desire; There is a push or initiative from within the government to carry out reforms and support the development of e-Government within the organization; c. Overall Vision and Strategy; Holistic and detailed planning for developing e-Government, able to determine how to start and where to go; d. Effective Project 
Management; The existence of clear responsibilities, good planning, consideration of risks, control and monitoring, good resource management, and good management of cooperative relations between the government and the private sector; e. Effective Change Management, which requires leadership abilities that have high vision and professionalism in carrying out their duties as public servants, to form a work environment that is conducive to developing eGovernment; f. Requisite Competencies, the development of e-Government supported by resources that have expertise and mastery of knowledge, especially within the government itself, whose employees have a broad mindset in innovating, creating services desired by the public and stakeholders in developing e-Government; g. Adequate Technological Infrastructure is the use of information technology used in e-Government development that must vary.

Based on the results of expert research above, it can be seen that there is a relationship between work-culture and happiness at work that is felt by employees at work. Work culture has a large and positive causal effect on happiness, resulting in optimal work performance. Although, during the industrial era 4.0 that is currently taking place, many have also argued that the current work culture is no longer relevant to happiness, because of the rapid use of artificial intelligence (AI). The development of AI is so fast that they can do various things, such as become virtual assistants, conduct analysis, conduct strategy studies, and various applications used for digital-based public services.

The impact of the use of AI in information technology causes human work to be replaced by machines or robots, meaning that the issue of productivity is no longer relevant. The productivity of employees is no longer an indicator to be highly rated, low, happy, or unhappy employees seem insignificant. A machine if it has been calibrated, it will get near-perfect results. Whereas humans, even though they have been trained, motivated, facilitated, have their salaries increased, it is still like the weather is sometimes sunny, hot, or rainy, the conditions are uncertain and difficult to predict.

But even though in some ways AI has advantages, humans still have many advantages by adapting to advances in information technology because humans have certain abilities that even the most sophisticated computers don't have. Based on the above theory, in this study, researchers formulated indicators of happiness, namely; availability of leisure time, interpersonal relations, environment and security, facilities, life autonomy, as well as integrative functions and satisfaction.

Furthermore, by the progress of the times and current developments, the employees and the public have used many activities using electronic and digital devices. So that office activities and services to the public are now mostly carried out electronically, thus the work culture among employees must automatically adjust to the development of technology and information.

Based on the explanation of some of the theories above, it can be seen that Electronic in E-Office means that all work related to office administration is done electronically and uses the help of communication tools and information systems. With the development of technology all through or high-speed and the internet, the office has become electronically. Office work that is done manually has turned into electronic and even some have implemented virtual offices. Electronic office uses communication technology to provide office administration services electronically to anyone, anywhere, at any time.

\section{Work Culture with Digital Governance-Based}

Work culture is a philosophy based on a person's view of life, which has become the values, habits, and forces that drive a person or organization. These values are then reflected in attitudes, which then become behavior, beliefs, ideas, views, and actions [11]. Work culture can provide a perspective of positive and negative values in understanding the work methods, 
norms, mindset, and behavior of a person or group in doing a job [14]. Work culture as a visible or invisible basis in a person, viewed from the perspective of values and beliefs, understanding how to work, norms, patterns of thought, and the behavior of any person or group of people who can help achieve organizational goals if accompanied by good leadership, healthy communication, awareness of time, and a fair reward and punishment system [15]; [16]). Furthermore, Aldri states that work culture indicators include (a) Leadership; (b) Appearance; (c) Awareness of time; (d) Communication; (e) Awards and recognition; (f) Values and beliefs.

Concerning this, the concept of work culture in this study is based on digital governance which is meant is the work culture of employees in carrying out work done on a digital/electronic basis. Such activities are related to the use of e-office, the use of social media such as WhatsApp, Facebook, Twitter, Instagram, and other social media. The use and arrangement of websites, applications used in government activities, including local government.

Furthermore, the measurement component in this study is related to digital governance (egovernance) which includes 4 components, namely; (1) cooperation between employees in providing data and information in an integrated manner; (2) the ability of agencies to provide data, and information to the public online; (3) availability of online applications in services; (4) agency responses to feedback from the public through applications or online.

\section{Methodology}

This study used a quantitative approach with an associative type. This type of associative research was looking for a relationship or influence between two or more variables. According to Sugiyono [17], the population is a generalization area consisting of objects/subjects that have certain qualities and characteristics that are determined by researchers to study and then draw conclusions.

The population in this study were employees in the organization of regional devices in the city of Pariaman. The sampling technique used nonprobability sampling with a purposive sampling type. However, due to the atmosphere of the Covid-19 pandemic that occurred at the time of data collection, the data collected in the distribution of questionnaires using google form and printed questionnaires were 66 respondents who filled out the questionnaire from the Human Resources and Human Resources Development Agency, the Financial Management Agency. and Regional Revenue, Archives and Libraries Section, Youth and Sports Service, Communication and Information Technology Office, Tourism and Culture Service, Education Office, Industry Service, Cooperatives and Small and Medium Enterprises, Public Housing Service, Residential Areas, and the Environment, Police Unit Service and Fire Department, Population and Civil Registry Office, Office of National Unity and Politics, Secretariat of the Regional People's Representative Council, Pariaman City.

Furthermore, the collected data was processed using multiple linear regression analysis which was processed through the SPSS version 21 program, to analyze the effect of one or more independent variables on the dependent variable. 


\section{Finding and Discussion}

\subsection{Result}

Based on the questionnaire data, the respondent profile is presented as follows.

Table 1. Profile of Research Respondents

\begin{tabular}{|c|c|c|c|c|c|c|c|}
\hline Gender & & Education & & Age & & $\begin{array}{l}\text { Length of } \\
\text { Work }\end{array}$ & \\
\hline \multirow[t]{2}{*}{ Male } & 27 & $\begin{array}{l}\text { Elementary School/ } \\
\text { Equivalent }\end{array}$ & 0 & $<20$ & 0 & $0-5$ Years & 11 \\
\hline & & $\begin{array}{l}\text { Junior High School / } \\
\text { Equivalent }\end{array}$ & 0 & $21-30$ & 4 & $5-10$ Years & 8 \\
\hline \multirow[t]{4}{*}{ Female } & 39 & $\begin{array}{l}\text { Senior High School/ } \\
\text { Equivalent }\end{array}$ & 10 & $31-40$ & 38 & $10-15$ Years & 23 \\
\hline & & Diploma II & 4 & $41-50$ & 18 & $15-20$ Years & 14 \\
\hline & & $\begin{array}{l}\text { Bachelor/Diploma } \\
\text { IV }\end{array}$ & 38 & $\begin{array}{c}50<\text { and } \\
\text { above }\end{array}$ & $60-$ & $20-25$ Years & 2 \\
\hline & 66 & $\begin{array}{l}\text { Masters/Spesialists } \\
\text { Total }\end{array}$ & $\begin{array}{l}14 \\
66\end{array}$ & Total & 66 & $\begin{array}{l}25<\text { and above } \\
\text { Total }\end{array}$ & $\begin{array}{l}8 \\
66\end{array}$ \\
\hline
\end{tabular}

Based on the data in Table 1 above, it can be seen that the number of male and female respondents is more female than male, where the percentage of male respondents is $40.9 \%$, while the number of female respondents is $59,1 \%$. From the educational aspect, the profile of respondents with the highest percentage is Bachelor / Diploma IV, with a total of $57.6 \%$ or 38 people. There are no respondents for Elementary School/equivalent, Junior High School/equivalent, and Doctoral (S3) types. It can be concluded that the respondent's education has now improved from when he entered work. From age, that is the most in the range of 31 40 years with a percentage of $57.6 \%$ or 38 people. While respondents under the age of 20 do not exist or $0 \%$. From the length of work, those who have worked for a long time range from 10 - 15 years with a percentage of $34,8 \%$, or 23 people at the most. Meanwhile, respondents who have worked for a little while being respondents are those who have worked 20-25 years with a percentage of $3 \%$ or 2 people.

Then the results obtained based on data processing using the results of the normality test are presented below.

Table 2.Tests of Normality

\begin{tabular}{lrrrrrr}
\hline & \multicolumn{3}{c}{ Kolmogorov-Smirnov $^{\mathrm{a}}$} & \multicolumn{3}{c}{ Shapiro-Wilk } \\
& Statistic & df & \multicolumn{1}{c}{ Sig. } & Statistic & Df & \multicolumn{1}{c}{ Sig. } \\
\hline Organizational_Culture &, 087 & 66 &, $200^{*}$ &, 986 & 66 &, 676 \\
E_Gov &, 118 & 66 &, 023 &, 963 & 66 &, 044 \\
Happiness_Index &, 080 & 66 &, $200^{*}$ &, 979 & 66 &, 343 \\
\hline
\end{tabular}

*. This is a lower bound of the true significance.

a. Lilliefors Significance Correction

Based on the table. 2 Normality test in the table above we can see that the significant value is greater than 0.05 , where the significant value of work culture is $0.200(0.200>0.05)$, the significant value of e-governance is $0.123(0.123>0.05)$ and the value from the happiness index $0.200(0.200>0.05)$. It can be concluded that the value of each variable is normally distributed. 


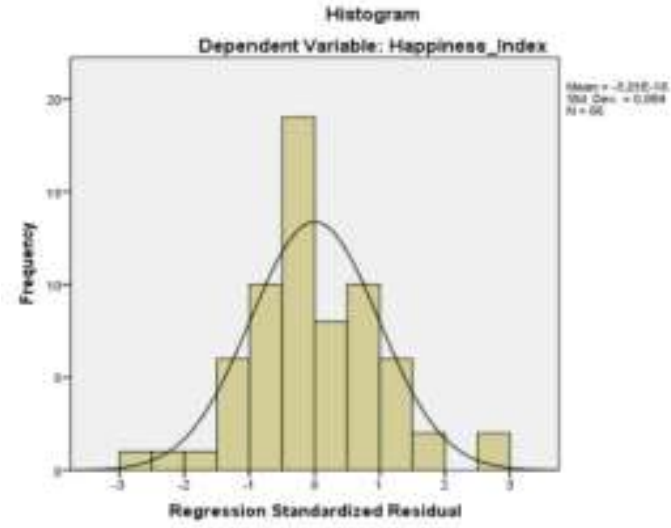

Fig. 1. Normality Test

Based on the picture above, the results of normality test data show good data analysis and it can be said that the research data is normally distributed and forms a normality curve.

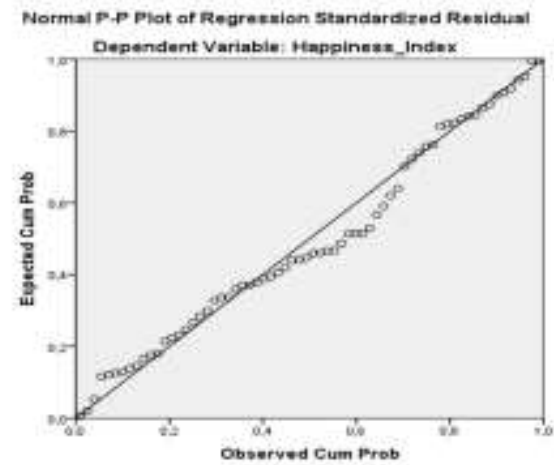

Fig. 2. Linearity Test

Based on the picture above, it can be seen that the data is normally distributed, which is indicated by the presence of dots along the line and does not spread to the extreme. This indicates that the data in this study qualify for a regression test because the data does not have a disruption in its distribution.

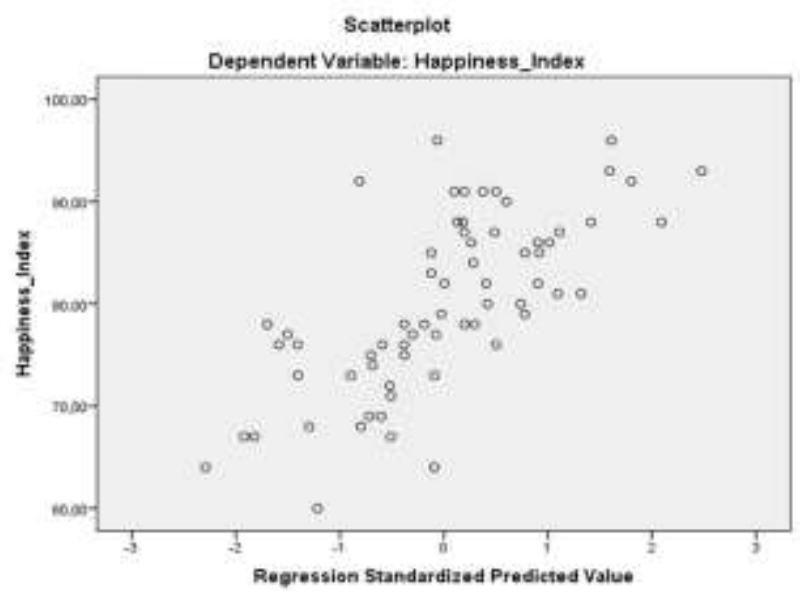

Fig. 3. Heteroscedasticity Test 
Based on the figure above, the dots represent the data scattered over the zeros on the $\mathrm{Y}$ axis. It is also seen that the dots do not form a specific pattern. Thus, it can be stated that there is no heteroscedasticity problem. In other words, in the X1 and X2 tests against $\mathrm{Y}$, there was no data deviation.

Table 3. Multicollinearity Test

\begin{tabular}{|c|c|c|c|c|c|c|c|}
\hline \multirow{4}{*}{$\frac{\text { Model }}{\text { (Constant) }}$} & \multicolumn{5}{|c|}{ Coefficients } & \multirow{2}{*}{\multicolumn{2}{|c|}{ Collinearity Statistics }} \\
\hline & \multicolumn{2}{|c|}{$\begin{array}{l}\text { Unstandardized } \\
\text { Coefficients }\end{array}$} & \multicolumn{2}{|c|}{$\begin{array}{l}\text { Standardized } \\
\text { Coefficients }\end{array}$} & \multirow[b]{2}{*}{ Sig. } & & \\
\hline & $\mathrm{B}$ & Std. Error & Beta & $\mathrm{T}$ & & Toler & VIF \\
\hline & 26,735 & 57,904 & & 3,383 & ,001 & & \\
\hline Organizational_Culture &, 584 &, 186 & 294 & 3,131 & ,003 & ,909 & 1,100 \\
\hline E_Gov & 1,840 & ,311 & ,556 & 5,916 &, 000 & ,909 & 1,100 \\
\hline
\end{tabular}

a. Dependent Variable: Happiness_Index

Based on table 3. above, it can be seen that the Tolerance value has a greater value than 0.10 . Meanwhile, the VIF value has a small value of 10 . With this, it can be stated that in this study there is no multicollinearity problem. This also states that there is no perfect correlation between research variables. While the regression test results are presented below.

Table 4. Regression Test Model Summary

\begin{tabular}{llccrrr}
\hline & & & Adjusted R & Std. Error of the & \\
Model & $\mathrm{R}$ & R Square & Square & Estimate & Durbin-Watson \\
\hline 1 &, $703^{\mathrm{a}}$ &, 494 & &, 478 & 6,20777 & 2,306 \\
\hline
\end{tabular}

a. Predictors: (Constant), E_Gov, Organizational_Culture

b. Dependent Variable: Happiness_Index

Based on the table 4. the calculation of the coefficient of determination shows that Adjusted R2 is 0.478 which is equal to $47.8 \%$, this means that the variation in changes in the happiness index variable is influenced by the work culture and e-governance variables by $47.8 \%$. Meanwhile $52.2 \%$ is influenced by other variables outside of this study.

Table 5. Test ANOVA ${ }^{\mathrm{a}}$ test

\begin{tabular}{llrrrrr}
\hline Model & & Sum of Squares & df & Mean Square & F & Sig. \\
\hline 1 & Regression & 2374,826 & 2 & 1187,413 & 30,813 &, $000^{\mathrm{b}}$ \\
& Residual & 2427,795 & 63 & 38,536 & & \\
& Total & 4802,621 & 65 & & & \\
\hline
\end{tabular}

a. Dependent Variable: Happiness_Index

b. Predictors: (Constant), E_Gov, Organizational_Culture

From the table. 5 above, it can be seen that the probability (p-value) for work culture and e-governance is 0,000 smaller than the $\alpha$ value $(\alpha=0.05)(0,000<0.05)$, it means that work culture and e-governance are together have an effect on the happiness index. 
Table 6. Coefficients ${ }^{\mathrm{a}}$

\begin{tabular}{|c|c|c|c|c|c|c|}
\hline & \multirow[b]{2}{*}{ Model } & \multicolumn{2}{|c|}{$\begin{array}{l}\text { Unstandardized } \\
\text { Coefficients }\end{array}$} & \multirow{2}{*}{$\begin{array}{c}\text { Standardized } \\
\text { Coefficients } \\
\text { Beta } \\
\end{array}$} & \multirow[b]{2}{*}{$\mathrm{t}$} & \multirow[b]{2}{*}{ Sig. } \\
\hline & & B & Std. Error & & & \\
\hline \multirow[t]{3}{*}{1} & (Constant) & 26,735 & 7,904 & & 3,383 & ,001 \\
\hline & $\begin{array}{c}\text { Organizational_ } \\
\text { Culture }\end{array}$ &, 584 & , 186 & ,294 & 3,131 & ,003 \\
\hline & E_Gov & 1,840 & ,311 & ,556 & 5,916 & ,000 \\
\hline
\end{tabular}

a. Dependent Variable: Happiness_Index

Based on the data above, it can be seen that part there is an influence of work culture on the happiness index with a significance of 0.03 . This indicates that the effect of $\mathrm{X} 1$ on $\mathrm{Y}$ can be trusted to be $100 \%$ correct, while the beta value of the partial test results is 0.294 . And in the data above, partially there is an effect of e-governance on the happiness index with a significant amount of 0.000 . This shows that the influence of X2 on Y can be trusted to be $100 \%$ true, and the beta value of the partial results of e-governance is 0.556 .

\subsection{Discussion}

Based on the results of the research, it is found that there was an effect of happiness at work on employee work culture and e-governance as well as of both in work culture and egovernance whose effect on the happiness index. This study used multiple regression analysis and produced a positive correlation.

This study used the subject of employees which was one of the most important components in being the administration of government in Kota Pariaman. The success of the city government in building a work culture based on digital governance (e-governance) was very important in the current era of the industrial revolution 4.0. Moreover, at this time in various countries including in the area where research is ongoing with various efforts to prevent the spread of the COVID 19 outbreak, which causes various work-life activities of government administration and other activities to be carried out by using an online system, namely Work From Home (WFH).

Various changes in life with the development of the digital world that is taking place today and the atmosphere of preventing the COVID 19 outbreak which is also ongoing have caused many employees to use online tools to carry out work activities. Therefore, building happiness in the workplace including doing office work from home became very important. Because these were two different work environments in carrying out government administration work activities. Therefore, the work culture of employees has to be able to be harmonized with the two forms of the work environment. Although, when carrying out work activities from home there were several different things, in the view of the researcher regarding appearance for employees was not so important, different if they had to go to the office then the appearance becomes important because they had to wear uniforms with completeness by applicable regulations. Meanwhile, when the work is done from home, they may have their appearance according to the atmosphere in their respective homes. On the other hand, there was also a tendency that if the work is carried out with a dominant WFH could also cause boredom, because interaction with colleagues was no longer done by meeting physically, but online. So that the social atmosphere of employees with other employees or co-workers experienced a difference 
between the work activities carried out in WFH and those carried out directly in the office environment.

However, with the development of digital governance, various forms of public service and other administrative work have used many electronic and online systems or applications or other media uses such as WhatsApp and other online-based media. The results of this study indicated that there was a close relationship with the implementation of digital governance-based work carried out by employees with good cooperation between employees in providing integrated data and information. Regional apparatus organizations had also provided data and information for the public interest online, including services to the public in the form of online applications or other online media. Then, to my best knowledge in the new normal situation, many factors influence the happiness of the employees like working from home which can take care of their health, intense with the family, and flexibility time. Working with the use of high intensity of technology look like remote everything also makes it easy to finish their work than working with the conventional technique.

The results of this study were in line with the theory put forward by Pryce and Jones ([18]) that happiness at work was a positive feeling that an individual has at every working time, because the individual knows, manages, and influences the world of work to maximize performance and provide satisfaction for himself in work. Furthermore, Carr [18] the factors that influence a happy individual at work are culture, social support, and cooperation. Then according to Sousa, [19] organizational culture had a positive and significant effect on employee happiness. Organizational culture and happiness have a direct impact when doing work because of the interconnectedness of the environment, cultural values, and employe.

\section{Conclusion}

Based on the study results, it can be concluded that there was an influence of work culture on the happiness index with a significance of 0.03 , and it can be seen that the probability value of 0.000 was smaller than the value of $\alpha(\alpha=0.05)(0.000<0.05)$, so culture work and egovernance together affected the happiness index. These results indicated that there is a positive correlation that occurs in happiness in this study due to; (1) the availability of free time that can be obtained at work; (2) interpersonal relationships that take place in the workplace; (3) the environment and safety at work; (3) facilities in the workplace; (3) life autonomy which gives freedom in making personal choices in work; (4) integrative functions and satisfaction obtained at work. Also, it is hoped that this research can be used as a reference, to conduct similar research with different subjects or to develop research with other variables.

Acknowledgments. This article is part of the study results funded by DRPM at the DIPA of the Ministry of Research and Technology through the Institute for Research and Community Service at the State University of Padang with a research contract for the Master's thesis research scheme for the fiscal year 2020 No.820 / UN.35.13 / LT / 2020. Moreover, the researchers would like to thank the parties mentioned above. Then, thanks also to the Masters (S2) Students of the State Administration Science, Faculty of Social Sciences, Padang State University who have taken part in this research, namely Karyadi; Adelyn Alista Utami; Wahib Assyahri, as well as various other parties who cannot be named one by one. 


\section{References}

[1] M. E. Milakovich, "Digital governance and collaborative strategies for improving service quality," in KMIS 2014 - Proceedings of the International Conference on Knowledge Management and Information Sharing, 2014.

[2] S. Sinha, A. K. Singh, N. Gupta, and R. Dutt, "Impact of Work Culture on Motivation and Performance Level of Employees in Private Sector Companies," Acta Oeconomica Pragensia, 2010.

[3] R. Veenhoven, "Happiness," Database, vol. 16, no. 3, pp. 128-129, 2003.

[4] Cynthia D. Fisher, "Happiness at Work," Int. J. Manag. Rev., vol. 12, no. 4, pp. 384 412, 2010.

[5] R. Roy and J. Konwar, "Workplace happiness: A conceptual framework," Int. J. Sci. Technol. Res., vol. 9, no. 1, pp. 4452-4459, 2020.

[6] M. El-Sholkamy and T. Fischbach, "The Knowledge and Human Development Authority: Innovation in Human Resource Management and People's Happiness," pp. 251-270, 2019.

[7] N. R. A. Semedo, Arnaldo Coelho, "Authentic leadership, happiness at work and affective commitment: An empirical study in Cape Verde," Eur. Bus. Rev., 2019.

[8] T. Puji Rahayu, "Determinan kebahagiaan di Indonesia," J. Ekon. dan Bisnis, vol. 19, no. 1, pp. 149-170, 2016.

[9] V. Yulistia Rahayu, A. Frinaldi, and A. Khaidir, "The influence of green open space and tourism-conscious work culture on the happiness of the people in Solok Regency," in IOP Conference Series: Earth and Environmental Science, 2019.

[10] F. Rahmi, "Happiness at Workplace," pp. 32-40, 2019.

[11] B. Irawan, "Studi Analisis Konsep E-Government: Sebuah Paradigma Baru dalam Pelayanan Publik," Paradigma, vol. 2, no. 1, pp. 174-201, 2013.

[12] Y. Nurhadryani, "Memahami Konsep E-Governance serta Hubungannya dengan EGovernment dan E-Demokrasi," in Seminar Nasional Informatika, 2009, vol. 2009, no. semnasIF, pp. 111-117.

[13] P. Lumbanraja, "Pengaruh Karakteristik Individu, Gaya Kepemimpinan dan Budaya Organisasi terhadap Kepuasan Kerja dan Komitmen Organisasi ( Studi pada Pemerintah Daerah di Provinsi Sumatera Utara )," J. Apl. Manaj. |, vol. 7, no. 2, 2009.

[14] Aldri Frinaldi; Muhamad Ali Embi, "Influence of Public Service Quality in Citizen Satisfaction (Study in Private Hospital Y in Padang, West Sumatra Province)," J. Gov. Polit., vol. 6, no. APSPA, pp. 102-114, 2015.

[15] A. Frinaldi, Mengelola Budaya Organisasi Dan Budaya Kerja. Acuan Bagi Akademisi, Praktisi, dan Pemerhati Budaya Kerja. Kota Padang: UNP Press, 2017.

[16] Aldri Frinaldi, “The Influence of Driver Work Culture and Service Quality on Citizen Satisfaction with Mass Transportation," Proc. Int. Conf. Ethics Gov. (ICONEG 2016), vol. 84, no. Advances in Social Science, Education and Humanities Research, pp. 450453, 2017.

[17] Sugiyono, Metode Penelitian Kuantitatif, Kualitatif, dan R\&D., 2 Cetakan. Bandung: Alfabeta, 2019.

[18] Siska Wulandari and Ami Widyastuti, "Faktor - Faktor Kebahagiaan Di Tempat Kerja," J. Psikol. UIN Sultan Syarif Kasim Riau, vol. 10, no. Juni, pp. 41-52, 2014.

[19] J. M. De Sousa and J. B. Porto, "Happiness at work: Organizational values and personorganization fit impact," Paideia, vol. 25, no. 61, pp. 211-220, 2015. 